\title{
CLINICAL-MORPHOLOGICAL CHARACTERISTICS AND PECULIARITIES OF TREATMENT OF PARAURURICULAR FISTULAS IN CHILDREN
}

DOI: 10.36740/WLek202006120

\author{
Pavlo I. Tkachenko, Ivan I. Starchenko, Serhii O. Bilokon, Yuliia V. Popelo, Nataliia M. Lokhmatova, Olha B. Dolenko, \\ Nataliia M. Korotych, Andrii M. Hohol, Nataliia P. Bilokon \\ UKRAINIAN MEDICAL STOMATOLOGICAL ACADEMY, POLTAVA, UKRAINE
}

\begin{abstract}
The aim: Determining the frequency of occurrence of paraauricular fistula in children and comparing the results of their own experience regarding their clinical manifestations, treatment principles and morphological features with existing scientific data.

Materials and methods: The results of a comprehensive examination and surgical treatment of 25 children with paraauricular fistulas.

Results: Most often, para-auricular fistula was observed in infants 22 - (88\%). In 18 persons (72\%), they were unilateral, in 10 - (40\%) hereditary. In 8 - (32\%), fistula was diagnosed immediately after birth. In 17 - (68\%) the pathology was not clinically manifested, but was an accidental finding during the next medical examination. Morphological research has shown that congenital paraauricular fistula is a formed canal intimately associated with the epithelium and cartilage, and the presence of epithelial lining on the fistula wall with constant support of the inflammatory process makes it impossible to heal even against the background of multicomponent treatment.

Conclusions: Due to the topographic-anatomical localization, features of the clinic of the born fistula, surgical treatment does not always allow to achieve the desired results, and requires repeated interventions during recurrence. It is possible to prevent recurrence by the extensive use of additional diagnostic manipulations before surgery and careful wound control during surgical procedures.
\end{abstract}

KEY WORDS: children, paraauricular fistulas, clinical manifestations, treatment

\section{INTRODUCTION}

It is well known that paraauricular fistulas (PAF) can be dysentogenic or acquired pathology. According to the researchers, congenital PAF is the result of impaired formation of the auricle in embryogenesis, resulting from the non-fusion of the dorsal end of the first gill slit. Most often, such pathology, in $25 \%$ of the observations having an inherited nature and transmitted by recessive type, is already determined in newborn children and occurs, depending on the region, with a frequency of $15,5-43,7$ cases per 100,000 people $[1,2,3,4,5,6,7]$.

Instead, acquired PAF is usually a complication of surgery or a prolonged purulent process in the parotid or masticatory area (otitis, mastoiditis, tonsillitis, etc.) $[8,9,10,11,12]$.

\section{THE AIM}

The purpose of the study is to determinew the incidence of PAF in children and to compare the results of their own experiences with regard to their clinical manifestations, treatment principles and morphological features with existing scientific data.

\section{MATERIALS AND METHODS}

We have thoroughly analyzed fundamental scientific works and publications in periodicals on these issues.
The frequency of occurrence of PAF was determined at the outpatient reception staff of the Department of Pediatric Surgical Dentistry, with the subsequent referral of patients to the hospital. The final diagnosis was determined by summarizing the results of general clinical and additional examination methods. Surgical treatment was performed according to the classical principles, but the choice of access and the amount of surgical intervention depended on the individual topographic and anatomical features of the location of the fistula.

The staff of the Department of Pathological Anatomy with a section course on preparations made from postoperative material according to conventional methods [13], determined the microscopic structure of the PAF.

\section{RESULTS AND DISCUSSION}

According to scientists, during the 5th and 6th weeks of gestation I and II, the gill arches give rise to six ear buds that form around the first brachial cleft from which the external auditory canal develops. The tubercles, in turn, form the structures of the auricle: they assume that the I hump "gives" the kid, II - the leg of the curl, III - the other part of the curl, IV - the antitumor, V - the lower part of the curl and ear lobe $[14,15]$. 
Therefore, PAF may result from incomplete fusion of the I tuberculosis, isolation of the ectodermal fold in the formation of the auricle, or impaired splicing of the first gill slit, which may be both sporadic cases and family inheritance with incomplete clinical manifestations $[1,3,4,6,9,10,16]$.

In view of the above, it is quite clear that most of the PAFs were observed in infants $(22(88 \%)$ of the 25 cases). Usually they were one-sided (18 persons - 72\%). In cases of bilateral fistulas, we do not determine the natural symmetry of their anatomical location.

It was found out that in 10 cases $(40 \%)$ of PAF were hereditary. Only 8 children (32\%) were diagnosed with congenital PAF in the maternity ward immediately after delivery, and this was in cases with clear clinical signs and the location of fistulas in front of the goat ear. In the other 17 patients (68\%), the pathology was clinically in no way manifested, and the presence of a "crater" at the fistula exit point did not disturb either the child or her relatives, but was an accidental finding during a regular examination at a pediatrician or surgeon. At the same time, attentive parents observed periodic isolation in a small amount of transparent or white mass of secretions, which, for the most part, was preceded by acute catarrh of the upper respiratory tract, but they were not interested in the "speck" from which these secretions were.

In the objective examination, the ears of the auricle and upwards of the curl (however, there were cases of other location in the para-auricular area) were often found to have a point hole of the fistula mouth no larger than $1 \mathrm{~mm}$ in diameter. In 19 cases (76\%) in the period of exacerbation, a thick mucus, serous mucous secretion or white mushy mass was released from the exacerbation period, which in some cases led to maceration of adjacent skin (Fig. 1,2).

Researchers note that poor development or presence of blockage in the course of fistula in some cases does not allow to determine the external opening of the PAF immediately after birth (Fig. 1b), and after infection and inflammation of the fistulas, the exit hole is formed naturally or artificially $[2,3,7,17]$.

There are two types of PAF. The first is a duplication of the cartilaginous part of the external auditory canal and opens in the pre- or retroauricular areas, and the second type is often combined with defects in the development of the ear, being a duplicate of the entire external auditory canal. It is with the second type on one (inner) side that the opening can open near the tympanic membrane, and on the other is located at the bottom of the external auditory canal or in the area of the cheek, the angle of the lower jaw, the upper (above the hyoid bone) of the neck. Sometimes PAF is combined with sensoneural deafness and is an integral part of the autosomal dominant bronchio-oto-renal syndrome $[1,4,6,10,16]$.

Sensing a thin polyethylene catheter, we have always identified a thin tortuous course of various sizes from 0,5 to $3-4 \mathrm{~cm}$ long. However, other researchers have found longer fistulous passages that open into the mouth, neck, or middle ear, and mention fistula with a canal width of 1 $\mathrm{cm}$ or more [10].
Infectious agents penetrating directly into the fistula may cause inflammation, which was observed in 19 patients (76\%). In such cases, deterioration of patients' general well-being, fever, tenderness, and other common signs of acute inflammatory diseases were determined, and pus was excreted from the fistula. The expressiveness of these manifestations was individual and dependent on many factors. Parents noted that similar phenomena in children from time to time have repeatedly occurred before, but did not bite without medical intervention. The frequency of development of inflammatory processes in different patients probably depended on the virulence of the microflora, the state of immunity of the patient and the anatomical features of the structure and size of the fistula.

We observed 1 patient (4\%) with acquired PAF, however, like other researchers, we note that their appearance is preceded by compaction, swelling, and formation of tubercles near the surface of the scar formed after the surgical wound, with redness and soreness in the area of the suture. against the background of fever, and then a small amount of purulent exudate begins to emerge. In addition, with purulent chronic otitis, especially on the background of an unsanitary oral cavity, fistula of the bone capsule of the labyrinth can also be formed $[2,7,9,12]$.

In our case, acquired PAF occurred 1 year after surgery to remove the parotid cyst (judging by the content of the extract from the medical history, which had no pathohistological confirmation). Unfortunately, we could not find out the exact issue because the patient was operated on in another clinic. In our opinion, this was a diagnostic error, and we dealt with relapse after incomplete removal of the fistula.

All children with the PAF who were treated at the clinic of the Department of Pediatric Surgical Dentistry under general anesthesia underwent surgical intervention to remove fistulous passages, which is the main method of treatment of this pathology. To determine the localization and distribution of fistula, a solution of diamond green or methylene blue was introduced into its outer opening immediately before surgery.

The fistula canal was removed with obligatory resection of the adjacent cartilage. The edges of the skin incision were mobilized, the wound was sutured in layers and drained with a rubber graduate, which was removed a day. The skin was sutured with a knotted suture as close as possible to the edge, which provided a further satisfactory cosmetic result.

In 1 case (4\%) after completely successful removal of PAF in the child in the postoperative period, a hypertrophic scar was formed, which did not undergo medical and physiotherapy leveling during 3-year dynamic observation (Fig. 3).

Paraauricular fistulas extend near the facial nerve, so surgery should be performed with utmost care. However, it should be remembered that short fistulas are fairly easy to cut in full, and long ones, which sometimes are quite curved, having a considerable length, need more careful and painstaking removal at full length.

Residues can cause recurrence of the pathology, which, according to Prasad et al (1990), reaches $42 \%$, and the scars 


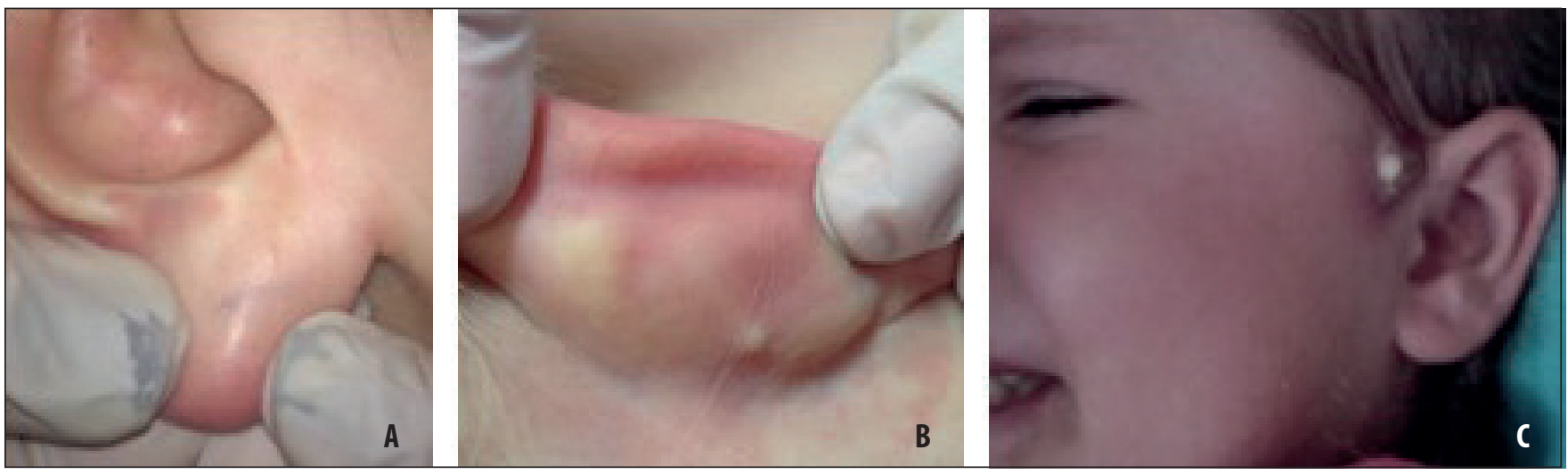

Fig. 1. $(a, b, c)$ The appearance of PAF of different anatomical localization in children.

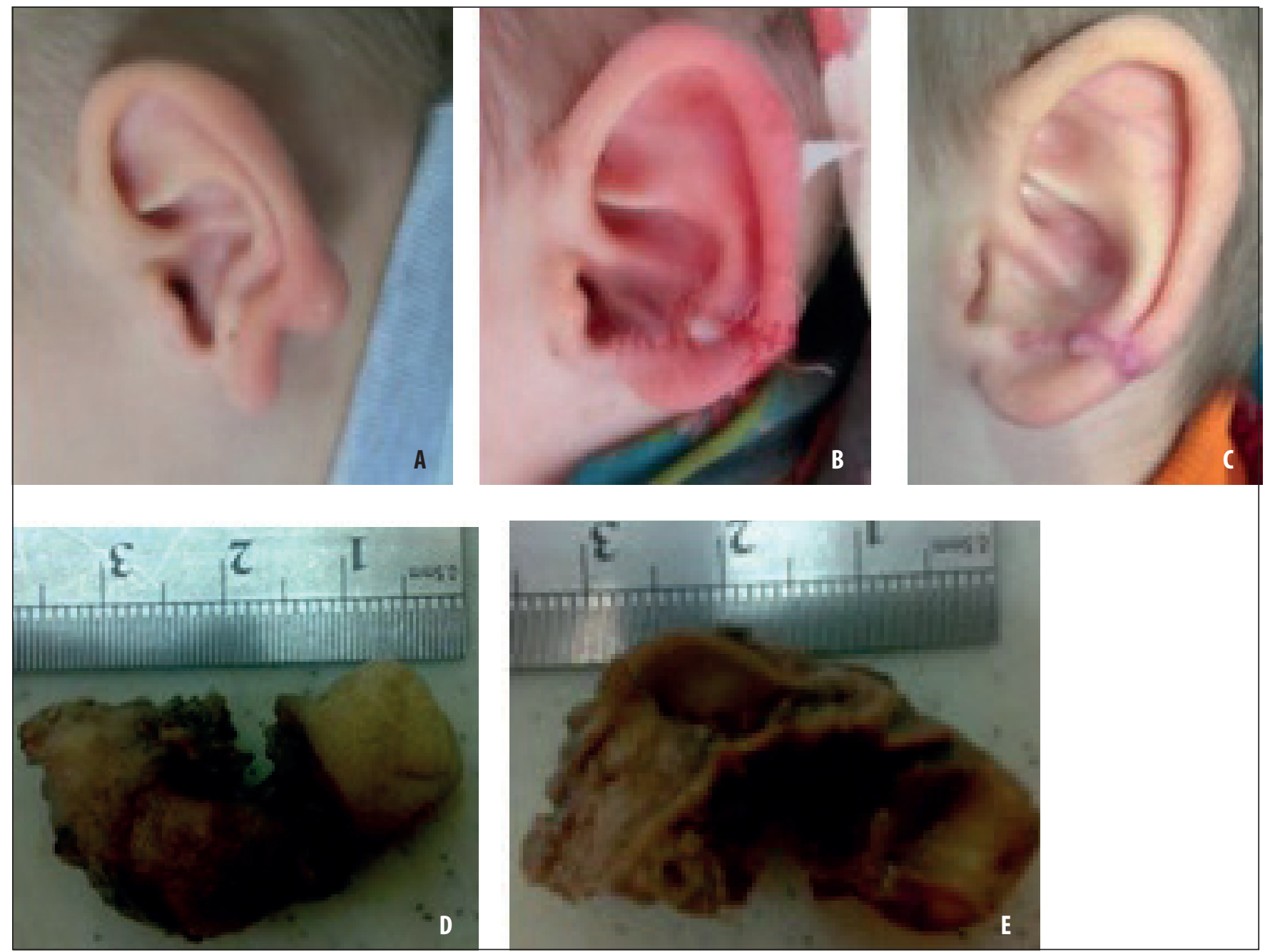

Fig. 2. The appearance (a-c) of PAF and macropreparation obtained after its removal $(d, e)$.

that occur in the case of unsuccessful surgery, mask the tissues of the fistula, complicating its complete removal in the future. To prevent this, prior to surgery, it is advisable to conduct a fistulograph to accurately determine the depth and branching of the stroke to determine the optimal variant of its excision.

In 6 cases $(24 \%)$, when PAFs were small, shallow, and not prone to inflammation, that is, they did not disturb the child, we did not perform any active intervention, limited only to dynamic observation.

For the purpose of elimination of inflammatory effects antibacterial, anti-inflammatory, symptomatic and local therapy - instillation into the fistula canal of antiseptic and antibacterial drugs was prescribed.

Against the background of acute inflammation, we did not perform radical surgery, limited, if it is necessary, by 


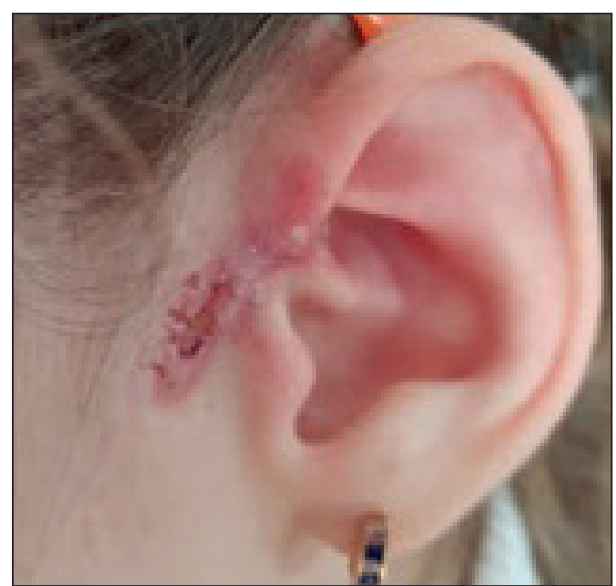

Fig. 3. The appearance of the hypertrophic scar formed in the postoperative period after removal of PAF in the child.

opening the abscess and eliminating its contents, followed by classic management of the purulent wound. After such treatment, usually the fistula was closed and a period of 1 month after the knocking out of the phenomena of inflammation, they underwent surgical removal. It should be noted that in 3 patients (12\%) fistulas functioned almost constantly without a significant period of remission, so they had to be operated immediately after elimination of manifestations of acute inflammation. Unfortunately, 2 of them $(66.7 \%)$ had recurrence again, accounting for $8 \%$ of the total number of patients.

After excision, all surgical material was sent for morphological examination, which revealed that the congenital PAF is a formed channel in the ear region (Fig. 2d, e), often intimately associated with the epidermis and cartilage, with the classical structure [17]. (Fig. 4, 5).

The fistula wall was formed by a dense fibrous connective tissue with a moderate number of cellular elements and a well-developed fibrillar component and the

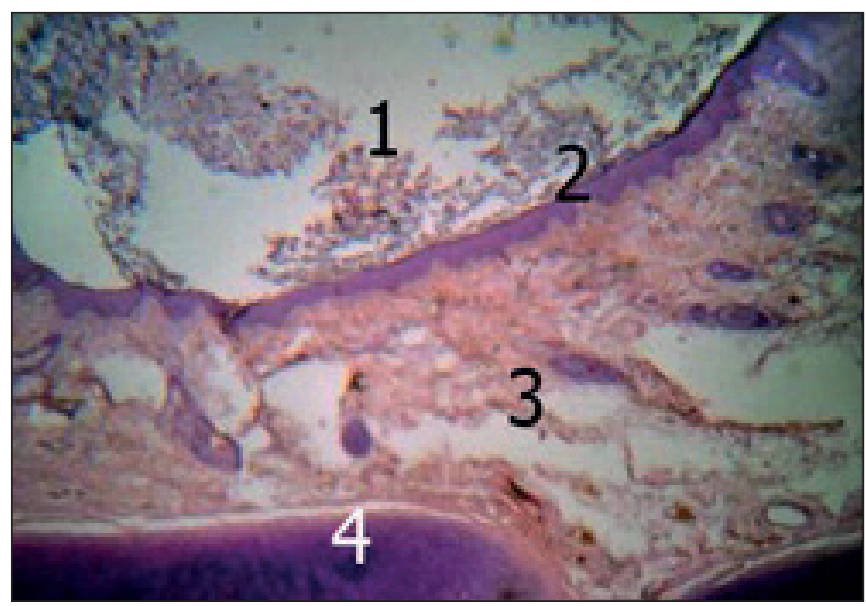

Fig. 4. General plan of the structure of the PAF. Micropreparation. Hematoxylin-eosinstaining. About. 4x, approx. 10x.

1 - fistula course;

2 - epithelial lining;

3 - coarse fibrous connective tissue;

4 - cartilage. presence, in most observations, of underdeveloped skin derivatives.

Among the connective tissue cells, mature fibroblasts prevailed in quantitative terms, sometimes grouping of lymphocytes and plasma cells, mainly located directly below the epithelial lining, were found. The presence of the latter indirectly indicates the presence of a long-lasting inflammatory process.

The epithelial lining was mostly formed by a multilayered flat, uncured epithelium with relatively clear stratification into separate layers, the cells of which had characteristic morphological features. Less often the fistula canal was lined by a multilayered cylindrical epithelium.

It is the presence of the described epithelial lining against the backdrop of constant support of the inflammatory process make it impossible to cure fistula even in the case of multicomponent conservative treatment [18].

\section{CONCLUSIONS}

Congenital forms of paraauricular fistulas in children are mainly diagnosed immediately after birth and during the first year of life. Due to the topographic-anatomical localization and peculiarities of clinical manifestations, they may be considered for other pathology with the treatment of doctors of different profiles already at the stage of pronounced inflammatory phenomena. In this regard, surgical treatment does not always achieve the desired results, requiring recurrent surgery for recurrence.

Unfortunately, there are no preventive measures of congenital PAF as a consequence of disorders of individual chains of embryogenesis. Instead, recurrence can be prevented by extensive use of additional examination methods and diagnostic procedures before surgery and careful wound control during surgical procedures.

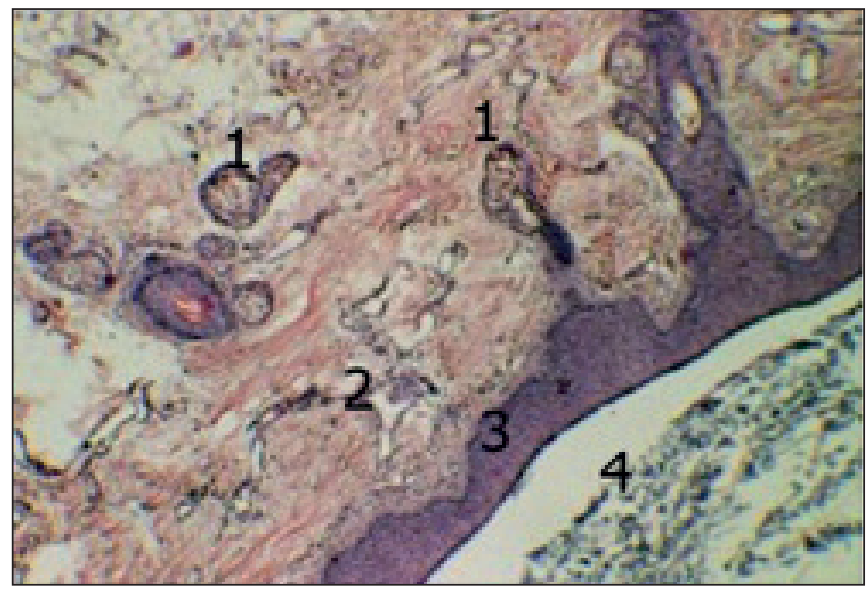

Fig. 5. The structure of the wall of the PAF. Micropreparation. Hematoxylineosin staining. About. 10x, Approx. 10x.

1 - skin derivatives;

2 - blood vessels;

3 - multilayered flat non-healing epithelium;

4 - cavity of the fistula. 


\section{PERESPECTIVES FOR FURTHER RESEARCH}

The above mentioned material can be the basis for further in-depth scientific and practical studies on the study of immunohistochemical features of paraauricular fistulas in order to determine their role in the clinical course, to determine individual features and to choose rational options for surgical access.

\section{REFERENCES}

1. Bernadskiy Yu.I. Osnovy chelyustno-litsevoy khirurgii i khirurgicheskoy stomatologii. [Fundamentals of maxillofacial surgery and surgical dentistry]. Moscow: Medical literature; 2000.404. (Ru)

2. Zelenskiy V.A., Mukhoramov F.S. Detskaya khirurgicheskaya stomatologiya i chelyustno-litsevaya khirurgiya [Pediatric surgical dentistry and oral and maxillofacial surgery]. Moscow: Medicine; 2008.206. (Ru)

3. MalanchukV.0., KonchakA.V. Dobroyakisni pukhlyny ta pukhlynopodibni urazhennia shchelepno-lytsevoi dilianky ta shyi [Benign tumors and tumorous lesions of maxillofacial area and neck]. Textbook. K.:Askania Publishing House; 2008.320. (Uk)

4. Timofeyev A.A. Chelyustno-litsevaya khirurgiya [Maxillofacial surgery]. K.: 2010.574. (Ru)

5. Tkachenko P.I., Starchenko I.I., Bilokon S.0. ta in. Novoutvorennya shchelepno-lytsevoyi dilyanky u ditey [Formations of maxillofacial area in children]. Poltava: 2018.191. (Uk)

6. Khar'kov L.V., Yakovenko L.M., Chekhova I.A. Khirurhichna stomatolohiya dytyachoho viku [Surgical dentistry of childhood]. Kyiv: Book Plus, 2003.480. (Uk)

7. Cherstvoy Ye.D., Kravtsovoy G.I., Furmanchuk A.V. Opukholi i opukholepodobnyye protsessy u detey [Tumors and tumor-like processes in children]. Minsk: Askar; 2002.400. (Ru)

8. Tkachenko P.I., Gurzhiy 0.V., Bilokon S.O. ta in. Dytiacha khirurhichna stomatolohiia. Praktychni zaniattia (Chastyny I-III). Metodychni rekomendatsii [Pediatric surgical dentistry. Practical classes (Parts I-III). Methodical recommendations]. Poltava: 2005.140. (Uk)

9. Kolesov A.A., Vorob'yov Yu.I., Kasparova N.N. Novoobrazovaniya myagkikh tkaney i kostey litsa u detey i podrostkov [Neoplasms of soft tissues and facial bones in children and adolescents]. Medicine, 1989.302. (Ru)

10. Kruchinskiy G.V. Redkiye vrozhdonnyye sindromy litsa i chelyustey [.Rare congenital syndromes of the face and jaw]. Minsk: Belarus; 1974.63. (Ru)

11. Tkachenko P.I., Starchenko I.I., Bilokon S.0. ta in. Dobroyakisni novoutvorennya m"yakykh tkanyn shchelepno-lytsevoyi dilyanky ta slynnykh zaloz u ditey [Benign neoplasms of the maxillofacial area and salivary glands in children]. Poltava: 2015.80. (Uk)

12. Topolnitskiy 0.Z. Stomatologiya detskogo vozrasta. Khirurgiya [Dentistry of childhood. Surgery]. Moscow: GEOTAR-Media; 2016.311. (Ru)
13. Merkulov A.B. Kurs patogistologicheskoy tekhniki [The course of pathological technology]. L.: Medicine; 1969.237. (Ru)

14. Bykov V.L. Gistologiya i embriologiya organov polosti rta cheloveka [Histology and embryology of the human oral cavity]. [2nd ed., Rev.] St. Petersburg: Special literature; 1998.247. (Ru)

15. Gemonov V.V., Lavrova E.N., Falin L.I. Razvitiye i stroyeniye organov rotovoy polosti i zubov [The development and structure of the organs of the oral cavity and teeth]. M.: GOUVUNMTS Ministry of Health of the Russian Federation; 2002.256. (Ru)

16. MalanchukV.0. Khirurhichna stomatolohiya ta shchelepno-lytseva khirurhiya [Surgical dentistry and maxillofacial surgery]. K.: Logos; 2011;1:669. (Uk)

17. Pal'tsev M.A., Anichkov N.M. Atlas patologii opukholey cheloveka [Atlas of the pathology of human tumors]. M .: Medicine; 2005.424. (Ru)

18. Vantsyan E.N. Naruzhnyye i vnutrenniye svishchi [External and internal fistulas]. M .: Medicine, 1990.221. (Ru)

The paper is written within the research study entitled "Integrative-and-differential substantiation of the choice of optimal methods of surgical interventions and the scope of therapeutic activities in the surgical pathology of the maxillofacial area" (State Registration No. 0116U003821).

\section{ORCID and contributorship:}

Pavlo I. Tkachenko - 0000-0001-5734-8137 A,B,C,F

Ivan I. Starchenko - 0000-0002-6666-1448 A,B

Serhii O. Bilokon - 0000-0002-7800-0516 ${ }^{A, D, F}$

Yuliia V. Popelo - 0000-0003-0002-366 ${ }^{A, E, F}$

Nataliia M. Lokhmatova - 0000-0002-7800-0516 ${ }^{E, F}$

Olha B. Dolenko - 0000-0002-7264-4206 E,F

Nataliia M. Korotych - 0000-0003-1893-2554 E,F

Andrii M. Hohol - 0000-0001-7979-6870 ${ }^{E}$

Nataliia P. Bilokon - 0000-0002-5979-5528 ${ }^{E}$

\section{Conflict of interest:}

The Authors declare no conflict of interest.

\section{CORRESPONDING AUTHOR Yuliia V. Popelo}

Ukrainian Medical Stomatological Academy

23 Shevchenka st., 36000 Poltava, Ukraine

tel: +380664603303

e-mail: yulia.kit71@gmail.com

Received: 03.03 .2020

Accepted: 07.05.2020 